\title{
Differential responses of GC-1 spermatogonia cells to high and low doses of bisphenol A
}

\author{
YUHUA LI, FEI DUAN, XIAOYU ZHOU, HONGJIE PAN and RUNSHENG LI
}

\begin{abstract}
Key Laboratory of Reproduction Regulation of National Population and Family Planning Committee, Shanghai Institute of Planned Parenthood Research, Institute of Reproduction and Development, Fudan University, Shanghai 200032, P.R. China
\end{abstract}

Received September 27, 2016; Accepted January 5, 2018

DOI: $10.3892 / \mathrm{mmr} .2018 .9256$

\begin{abstract}
Bisphenol A (BPA) is an environmental endocrine disruptor. The exact effect of BPA on spermatogenesis and the specific epigenetic effects on mouse spermatogonia remain to be elucidated. The present study exposed the GC-1 spermatogonial cell line to a series of differing BPA concentrations and examined the subsequent effects on cell proliferation, mitogen activated protein kinase (MAPK) signaling, DNA and histone methylation. A Cell Counting Kit-8 assay revealed that BPA significantly inhibited cell growth at the concentration of $10 \mu \mathrm{g} / \mathrm{ml}$, however no significant alterations were detected at lower BPA doses. The global DNA methylation levels were reduced at the dose of $10 \mu \mathrm{g} / \mathrm{ml}$ of BPA, via detection of 5-methylcytosine using a dot blot. The protein and mRNA expression levels of DNA methyltransferase (DNMT) 1 were decreased at 10 and $1 \mu \mathrm{g} / \mathrm{ml}$ of BPA, detected via western blotting and reverse transcription-quantitative polymerase chain reaction, respectively. The global levels of $\mathrm{H} 3 \mathrm{~K} 27 \mathrm{me} 3$ was decreased at $10 \mu \mathrm{g} / \mathrm{ml} \mathrm{BPA}$, detected via western blotting. Increased phosphorylation of p38 and decreased phosphorylation of extracellular signal-regulated kinases $1 / 2$ were observed at 10 and $1 \mu \mathrm{g} / \mathrm{ml} \mathrm{BPA}$. The results demonstrated that high and low doses of BPA exposure exhibit differential effects on cell growth, global DNA methylation, histone H3K9Me3 and H3K27Me3 levels and additionally affect the MAPK signaling pathways.
\end{abstract}

\section{Introduction}

Bisphenol A (BPA) is a high-production-volume chemical used in the manufacturing of polycarbonate and epoxy resins,

Correspondence to: Professor Runsheng Li, Key Laboratory of Reproduction Regulation of National Population and Family Planning Committee, Shanghai Institute of Planned Parenthood Research, Institute of Reproduction and Development, Fudan University, 2140 Xietu Road, Shanghai 200032, P.R. China

E-mail: runshengli2007@163.com

Key words: bisphenol A, spermatogonia, GC-1, methylation and is extensively used for the production of medical devices and plastic food packaging (1). Trace amounts of unreacted or additional BPA may be extracted from the materials, under conditions of high temperature or extreme $\mathrm{pH}$ (2). Bio-monitoring of BPA in human blood and urine indicates that human exposure to BPA is very universal $(3,4)$, primarily through oral exposure (5).

Previous studies suggest that high doses of BPA exposure may result in a variety of dysfunctions, including abnormal reproduction (6), metabolism (7) and mammary carcinogenesis (8). Conflicting data exists over the effects of low doses of BPA eon animal and human reproduction $(9,10)$. These contrasting data sets regarding effects of BPA may result from experiments on differing cell types and tissues, or BPA exposure routes and levels. However, the effect on mouse spermatogonia and the associated underlying mechanism of different doses of BPA exposure and subsequent effects, remains to be elucidated. The present study investigated whether the effects of high and low doses of BPA result in differential responses in spermatogonial cells, using the mouse cell line GC-1, which was immortalized by transformation with the plasmid pSV3-neo in type B spermatogonia (11).

The results of the present study demonstrated that high and low doses of BPA have differential effects on the levels of global DNA methylation, in addition to H3K9Me3, H3K27Me3, and mitogen activated protein kinase (MAPK) signaling, in mouse GC-1 spermatogonia cells.

\section{Materials and methods}

Cell culture. The mouse GC-1 spermatogonial cell line (American Type Culture Collection, Manassas, VA, USA) was grown in Dulbecco's modified Eagle's medium supplemented with $5 \%$ (v/v) fetal bovine serum (FBS; Gibco; Thermo Fisher Scientific, Inc., Waltham, MA, USA), 2 mM L-glutamine, and antibiotics (100 mg streptomycin/ml, $100 \mathrm{IU}$ penicillin/ml), in a humidified $\mathrm{CO}_{2}$ incubator at $37^{\circ} \mathrm{C}$.

Cell proliferation assay. For cell proliferation experiments, cells were seeded in 96-well cell culture plates at a density of 2000 cells per well and grown in free phenol red (Gibco; Thermo Fisher Scientific, Inc.) medium supplemented with 3\% charcoal-stripped FBS. BPA (Sigma-Aldrich; Merck KGaA, 
Darmstadt, Germany) was added at the final concentrations of $0.001,0.01,0.1,1$ and $10 \mu \mathrm{g} / \mathrm{ml}$ with five replicates and incubated for 5 days. Vehicle dimethyl sulfoxide (Sigma-Aldrich; Merck KGaA) was used as a negative control. A total of $10 \mu \mathrm{l}$ of CCK-8 solution (Dojindo Molecular Technologies, Inc., Kumamoto, Japan) was added to each well of the plate, then incubated for $2 \mathrm{~h}$ in the $\mathrm{CO}_{2}$ incubator, and the absorbance was measured at a wavelength of $450 \mathrm{~nm}$ using microplate reader.

Reverse transcription-quantitative polymerase chain reaction (RT-qPCR). Total RNA was isolated using TRIzol ${ }^{\circledR}$ reagent (Invitrogen; Thermo Fisher Scientific, Inc.) according to the manufacturer's protocol. The concentration and quality of total RNA were determined by absorbance ratio 260:280 using a spectrophotometer. cDNA was synthesized from $2 \mu \mathrm{g}$ total RNA using ReverTra Ace qPCR RT KIT (Toyobo Life Science, Osaka, Japan) for reverse transcription of mRNA. The resulting cDNA was diluted 10 -fold and used as template. qPCR was then performed using SYBRGreen real-time PCR Mix (Toyobo Life Science) using a BioRad MiniOpticon ${ }^{\mathrm{TM}}$ System under the following conditions: $95^{\circ} \mathrm{C}$ for $1 \mathrm{~min}$, and 40 cycles of $95^{\circ} \mathrm{C}$ for $15 \mathrm{sec}, 56-58^{\circ} \mathrm{C}$ for $15 \mathrm{sec}$ and $72^{\circ} \mathrm{C}$ for $45 \mathrm{sec}$. Immediately following the PCR, the melting curve was generated by raising the temperature from $60^{\circ} \mathrm{C}$ to $95^{\circ} \mathrm{C}$ and reading the fluorescence $1^{\circ} \mathrm{C} / 2 \mathrm{sec}$. Each gene was analyzed in triplicate. The expression of $\beta$-actin was used as an endogenous control and the $2^{-\Delta \Delta \mathrm{Cq}}$ method (12) was used to determine the relative expression of the genes. The primer sequences are listed in Table I.

Western blotting. Cell lysates were prepared using a cell lysis buffer for western blotting and immunoprecipitation (cat. no. P0013J, Beyotime Institute of Biotechnology), according to the manufacturer's protocol. The protein concentration was determined using a bicinchoninic acid assay (Beyotime Institute of Biotechnology). Subsequently, protein samples added with loading buffer were boiled for $5 \mathrm{~min}$ prior to sample electrophoresis. A total of $20 \mu \mathrm{g}$ proteins per lane was resolved by 10 or $15 \%$ SDS-PAGE according to different target protein and blotted on a $0.22 \mu \mathrm{m}$ polyvinylidene fluoride membrane (EMD Millipore, Billerica, MS, USA), which was blocked with 5\% skim milk in PBS-T buffer for $1 \mathrm{~h}$ at room temperature, followed by incubation with diluted primary antibodies for $1 \mathrm{~h}$ at $37^{\circ} \mathrm{C}$ (for anti- $\beta$-actin) or overnight at $4^{\circ} \mathrm{C}$ for the remaining antibodies. Following washing with PBS-T, the membrane was incubated with horseradish peroxidase-labeled goat anti-mouse immunoglobulin (Ig)G (1:3,000 in PBST; cat. no. A0216, Beyotime Institute of Biotechnology) or horseradish peroxidase-labeled goat anti-rabbit $\operatorname{IgG}(1: 3,000$ in PBST; cat. no. A0208; Beyotime Institute of Biotechnology) at $37^{\circ} \mathrm{C}$ for $1 \mathrm{~h}$. The blot was detected using SuperSignal ${ }^{\circledR}$ West Pico Chemiluminescent Substrate (Pierce; Thermo Fisher Scientific, Inc.) on X-ray films. The band intensity was measured by Gel-Pro analyzer (version 4.0; Media Cybernetics, Inc., Rockville, MD, USA) and normalized to a reference loading control.

The primary antibodies included: 1:500 diluted mouse anti-DNA methyltransferase (DNMT)1 monoclonal antibody (catalog no. ab13537; Abcam, Cambridge, UK); 1:2,000 diluted mouse anti- $\beta$-actin monoclonal antibody (catalog no. AA128; Beyotime Institute of Biotechnology); rabbit anti-extracellular signal-regulated kinase (ERK)1/2 polyclonal antibody (catalog no. AM076; Beyotime Institute of Biotechnology); 1:1,000 diluted mouse anti-phosphor-ERK1/2 (Thr202/Tyr204) monoclonal antibody (catalog no. AM071; Beyotime Institute of Biotechnology); 1:500 diluted mouse anti-p38 MAPK monoclonal antibody (catalog no. AM065; Beyotime Institute of Biotechnology); 1:500 diluted mouse anti-phospho-p38 MAPK (Thr180/Tyr182) antibody (catalog no. AM063; Beyotime Institute of Biotechnology); rabbit anti-H3K27Me3 polyclonal antibody (catalog no. Dam1387952; Upstate Biotechnology, Inc., Lake Placid, NY, USA); rabbit anti-H3K9Me3 polyclonal antibody (catalog no. Ab8898-100; Abcam); rabbit anti-histone H3 polyclonal antibody (catalog no. AH433; Beyotime Institute of Biotechnology).

Dot-blot assay. The dot blot assay was conducted as previously described (13). Briefly, cells were harvested for DNA isolation following BPA exposure for 5 days. Genomic DNA was extracted by classical proteinase $\mathrm{K} /$ phenol-chloroform methods, precipitated by mixing with $3 \mathrm{M}$ sodium acetate (pH 4.8) and cold ethanol. A total of 500 ng genomic DNA was denatured in $0.1 \mathrm{~N} \mathrm{NaOH}, 10 \mathrm{mM}$ EDTA at $95^{\circ} \mathrm{C}$ for $5 \mathrm{~min}$, and spotted on the nitrocellulose membrane. The membranes were washed with $2 \mathrm{xSSC}$ buffer, air-dried and baked at $80^{\circ} \mathrm{C}$ for $2 \mathrm{~h}$. Following blocking with $5 \%$ skim milk, the monoclonal 5-methylcytosine (mC) antibody (diluted 1:1,000 in PBST with 5\% skim milk; cat. no. I-MECY-0100, Eurogentec, Ltd., Southampton, UK) was incubated overnight at $4^{\circ} \mathrm{C}$. Following washing with TBST, membranes were treated with 1:2,000 dilution of horseradish peroxidase-conjugated goat anti-mouse IgG (catalog no. A0216, Beyotime Institute of Biotechnology) for $1 \mathrm{~h}$ at room temperature. The signals were visualized using SuperSignal ${ }^{\circledR}$ West Pico Chemiluminescent Substrate (Pierce; Thermo Fisher Scientific, Inc.). The membranes were further stained with hematoxylin solution for $5 \mathrm{~min}$ at room temperature for quantity loading control.

Statistical analysis. Data are presented as the mean \pm and standard error of the mean. Statistical analysis was performed using one-way analysis of variance followed by the least significant difference post hoc test. All analyses were conducted using SPSS software, version 20.0 (IBM SPSS, Armonk, NY, USA). $\mathrm{P}<0.05$ was considered to indicate a statistically significant difference.

\section{Results}

$B P A$ exhibits varied effects on proliferation of $G C-1$ spermatogonia cell line. Effects of BPA on GC-1 cell proliferation were evaluated using a Cell Counting Kit-8 assay. Exposure to $100 \mu \mathrm{g} / \mathrm{ml}$ of BPA resulted in cell toxicity, leading to cell death. Exposure to $10 \mu \mathrm{g} / \mathrm{ml} \mathrm{BPA}$ inhibited cell growth by $33.5 \%$ relative to controls. However, there were no significant alterations in cell proliferation at other doses of BPA, although a slight increase of 10 and $17.1 \%$ compared to control was observed at concentrations of 0.1 and $1 \mu \mathrm{g} / \mathrm{ml}$ BPA, respectively (Fig. 1).

$B P A$ exhibits varied effects on MAPK signaling. The MAPK signaling pathways (p38, ERK1/2) exhibit important roles in 
Table I. Primers used for reverse transcription-quantitative polymerase chain reaction.

\begin{tabular}{lll}
\hline Gene & \multicolumn{1}{c}{ Forward $\left(5^{\prime}-3^{\prime}\right)$} & Reverse $\left(5^{\prime}-3^{\prime}\right)$ \\
\hline DNMT1 & ACTGCGTCTCGGTCATT & GTCTGTGCCTCCCTCCAT \\
Ezh2 & GTAGACACTCCTCCAAGAAAGAA & GATGGTCACAGGGTTGATAGTT \\
Suv39h1 & CTCTGCATCTTCCGCACTAAT & AGTCGCTCATCAAGGTTGTCTAT \\
-actin & GTCCCTCACCCTCCCAAAAG & GCTGCCTCAACACCTCAACCC
\end{tabular}

DNMT, DNA methyltransferase; Suv39h1, Suppressor of Variegation 3-9 Homolog 1; Ezh2, Enhancer of Zeste Homolog 2.

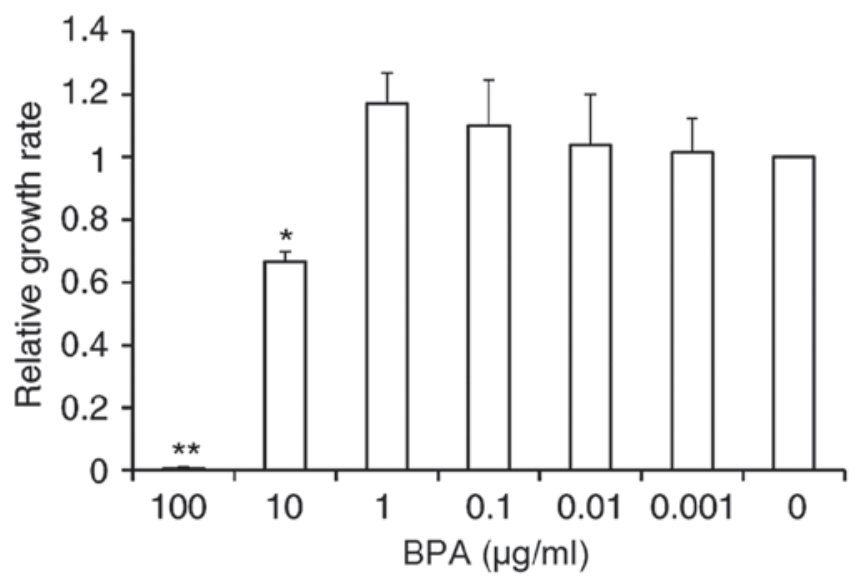

Figure 1. BPA effects on GC-1 cell proliferation. GC-1 cells were treated with BPA at differing concentrations from 0.001 to $100 \mu \mathrm{g} / \mathrm{ml}$, or $0.01 \%$ dimethyl sulfoxide vehicle for 5 days. Data are presented as the mean of three independent experiments. The error bars represent the corresponding standard error of the mean. ${ }^{* *} \mathrm{P}<0.01,{ }^{*} \mathrm{P}<0.05$ vs. control. BPA, bisphenol A.

cell proliferation and development (14). The present study next evaluated whether different doses of BPA had differential effects on the MAPK pathways in GC-1 spermatogonia cells. Western blot analysis revealed that BPA slightly increased the levels of p38 at all tested concentrations, except for $0.001 \mu \mathrm{g} / \mathrm{ml}$ of BPA, and enhanced the levels of phosphorylated p38 (p-p38) in a dose-dependent manner (Fig. 2A and B). BPA additionally increased the levels of extracellular ERK1/2 from 0.1 to $10 \mu \mathrm{g} / \mathrm{ml}$ BPA exposure. However, ERK1/2 phosphorylation markedly decreased at increased BPA concentrations (10 and $1 \mu \mathrm{g} / \mathrm{ml}$; Fig. 2A and C).

BPA decreases global DNA methylation. In order to investigate the role of BPA in global DNA methylation in mouse germ cells, dot-blot assays of DNA probed with an antibody specific to 5-mC were performed. Quantification of spot intensity revealed that the global 5-mC level was significantly reduced 2-fold at the high dose of $10 \mu \mathrm{g} / \mathrm{ml}$ BPA and slightly decreased by $21.2 \%$ at $1 \mu \mathrm{g} / \mathrm{ml}$ BPA (Fig. 3A).

Since global DNA methylation was altered following BPA exposure and DNA DNMTs control DNA methylation, the present study next determined the relative mRNA and protein expression of DNMT1 via RT-qPCR and western blot analysis. BPA exposure resulted in the significant reduction of DNMT1 mRNA expression at $10 \mu \mathrm{g} / \mathrm{ml}$ of BPA, and a smaller decrease in DNMT1 mRNA levels was observed at other concentrations of BPA (Fig. 3B). Consistent with the alterations in 5-mC levels, DNMT1 protein levels were significantly decreased by 85.6 and $77.2 \%$ at 10 and $1 \mu \mathrm{g} / \mathrm{ml} \mathrm{BPA}$, respectively. DNMT1 protein levels were increased 1.5 -fold at 0.01 and $0.001 \mu \mathrm{g} / \mathrm{ml}$ BPA exposure (Fig. 3C).

BPA exhibits varied effects on histone methylation. Methylation of lysine on histone $\mathrm{H} 3$ is the primary epigenetic modification of chromatin structure. Global levels of H3K9Me3, which is trimethylated $\mathrm{H} 3 \mathrm{~K} 9$, and $\mathrm{H} 3 \mathrm{~K} 27 \mathrm{Me} 3$, trimethylated H3K27, in BPA-treated GC-1 cells were analyzed by western blotting. As presented in Fig. 4A and B, the global levels of $\mathrm{H} 3 \mathrm{~K} 27 \mathrm{me} 3$ were decreased at the $10 \mu \mathrm{g} / \mathrm{ml}$ of BPA. However, the global H3K9me3 and H3K27me3 levels were increased from 0.01 to $1 \mu \mathrm{g} / \mathrm{ml}$ of BPA. Suppressor of Variegation 3-9 Homolog 1 (Suv39h1) and Enhancer of Zeste Homolog 2 (Ezh2) have been reported to respectively tri-methylate H3K9 and $\mathrm{H} 3 \mathrm{~K} 27$, therefore the present study evaluated the mRNA levels of Suv39h1 and Ezh2 in BPA-treated GC-1 cells using RT-qPCR. The analysis indicated that the mRNA levels of Suv39h1 and ezh2 were markedly decreased 2.5-fold at the high dose of $10 \mu \mathrm{g} / \mathrm{ml}$ of BPA; however, treatment with BPA at other concentrations did not significantly alter Suv39h1 and Ezh2 mRNA expression (Fig. 4C).

\section{Discussion}

The present study examined the effects of BPA on cellular proliferation of GC-1 cells, an immortalized type B spermatogonial cell line. Exposure to BPA for 5 days inhibited GC-1 cell proliferation at the high dose of $10 \mu \mathrm{g} / \mathrm{ml}$ of BPA, which suggested that BPA results in abnormal sperm development. An epidemiological study reported that urine BPA levels among BPA occupationally exposed workers are significantly associated with lower semen quality, including decreased sperm count and decreased sperm motility (15), revealing the deleterious effects of high doses of BPA exposure on male reproduction. Low concentrations of BPA have been reported to promote cell growth in the GC-1 and other cell lines. Stimulation of human testicular seminoma JKT-1 cell proliferation was observed at $24 \mathrm{~h}$ exposure to $10^{-5} \mathrm{M}$ $-10^{-12} \mathrm{M}$ of BPA (16). Sheng et al (17) reported that $10^{-7} \mathrm{M}-10^{-12}$ M BPA stimulates GC-1 cell proliferation following exposure to BPA for $12 \mathrm{~h}$. However, the present study did not observe cell stimulation at low concentrations of BPA exposure for 5 days. It was demonstrated that lower concentrations of BPA increased the GC-1 cell growth, although there was no 
A $\quad \begin{array}{llllllll}10 & 1 & 0.1 & 0.01 & 0.001 & 0 & \mu \mathrm{g} / \mathrm{ml} \text { BPA }\end{array}$
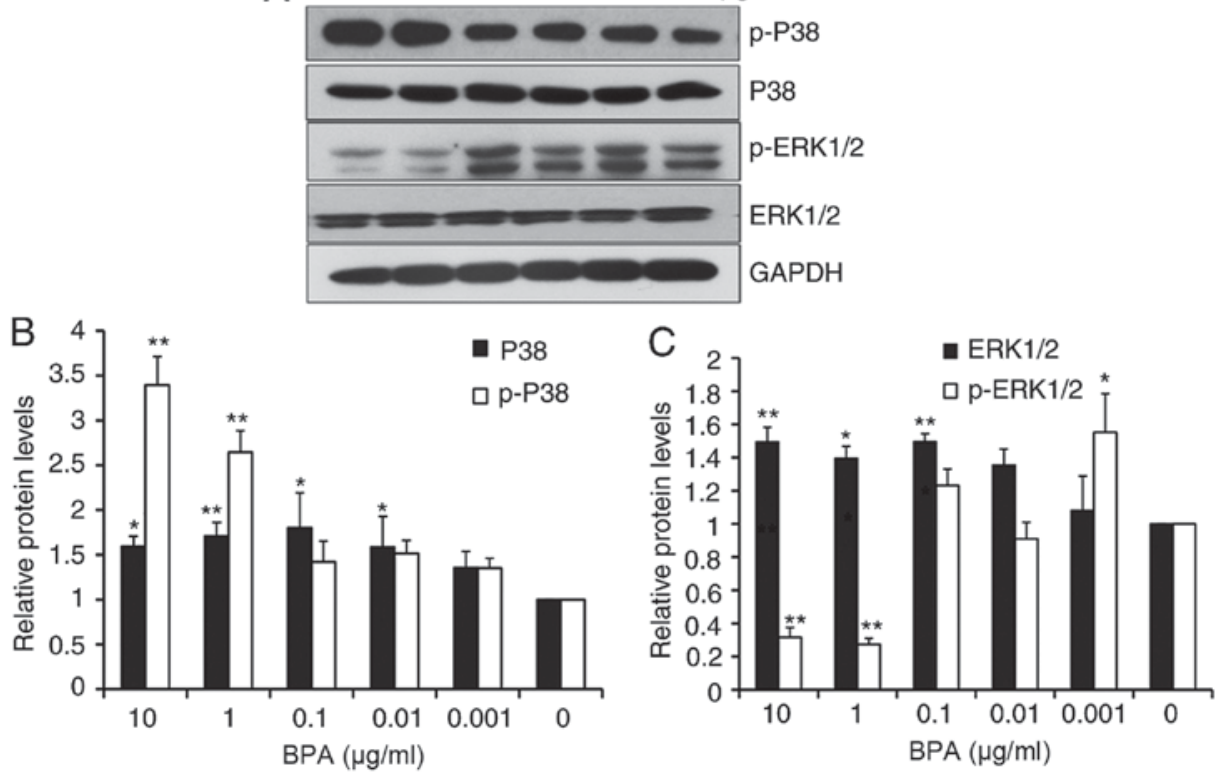

Figure 2. BPA effects on mitogen activated protein kinase signaling in GC-1 cells. (A) Representative western blot of the expression levels of p38, p-p38, total ERK1/2 and p-ERK1/2 following BPA exposure. Band values were normalized to GAPDH and compared to the control to obtain the relative expression levels of (B) p-p38 and total p38 and (C) p-ERK1/2 and total ERK1/2. Data are presented as the mean of three independent experiments. The error bars represent the corresponding standard error of the mean. ${ }^{*} \mathrm{P}<0.05,{ }^{* *} \mathrm{P}<0.01$. vs. control. BPA, bisphenol A; p, phosphorylated; ERK, extracellular signal-regulated kinase.
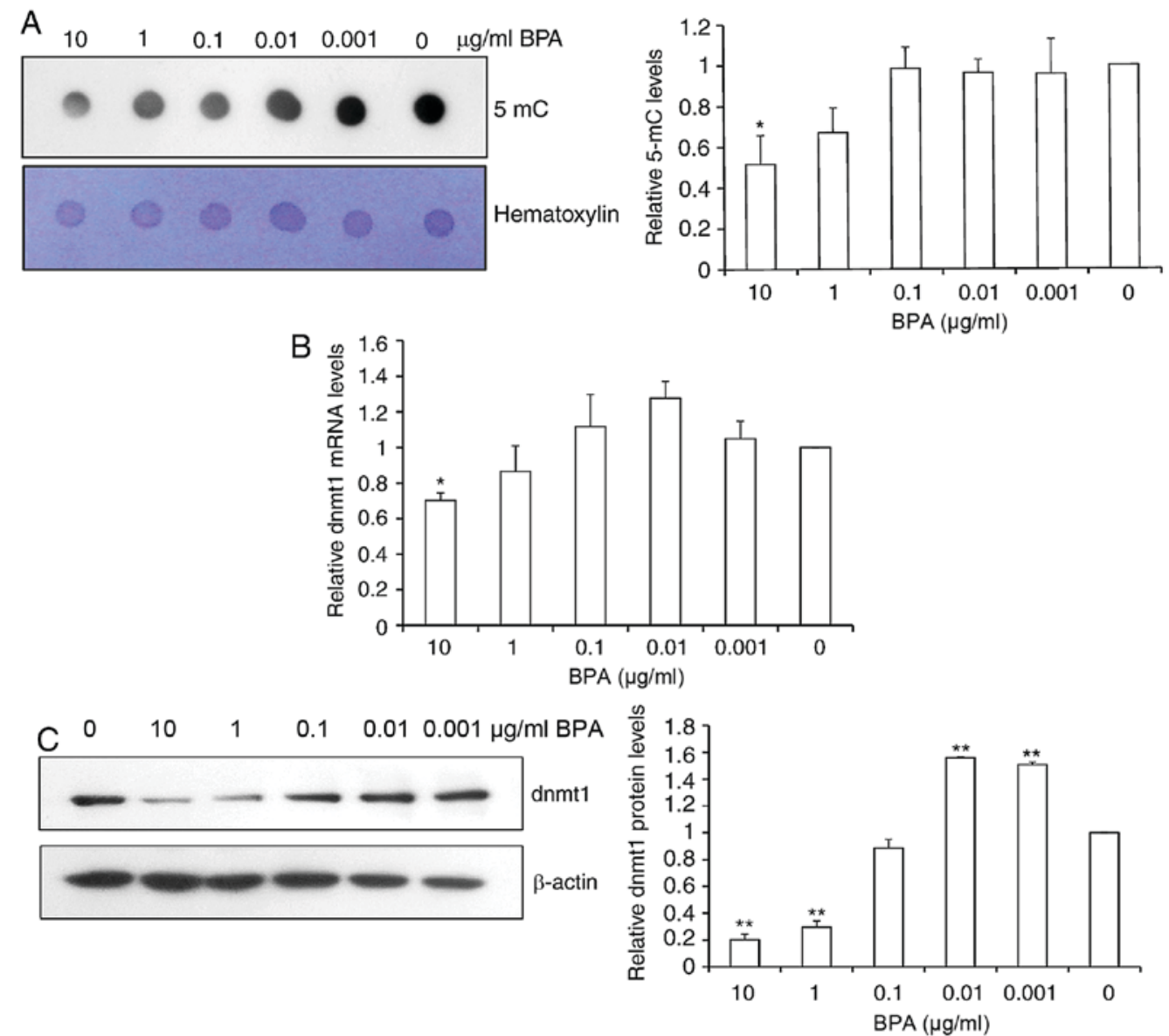

Figure 3. BPA effects on global levels of DNA methylation in GC-1 cells. (A) Dot-blot assay of global DNA methylation of GC-1 cells exposed to BPA using monoclonal 5-mC antibody. Dot blot presented in the top panel; the same membrane stained by hematoxylin as loading control in the bottom panel; Column values of 5-mC normalized to the loading control and compared with the control via densitometric analysis; Data are presented as the mean of four independent experiments. (B) Reverse transcription-quantitative polymerase chain reaction analysis of DNMT1 mRNA expression following BPA exposure. (C) Western blot analysis of cells treated with a series of concentrations of BPA. $\beta$-actin was used as internal control. Histogram represented relative DNMT1 protein levels normalized to $\beta$-actin and compared with control DNA by densitometric analysis. Data are presented as the mean \pm standard error of the mean of three independent experiments. ${ }^{*} \mathrm{P}<0.05,{ }^{* *} \mathrm{P}<0.01$ vs. control. BPA, bisphenol A; 5-mC, 5'methylcytosine; DNMT, DNA methyltransferase. 
A
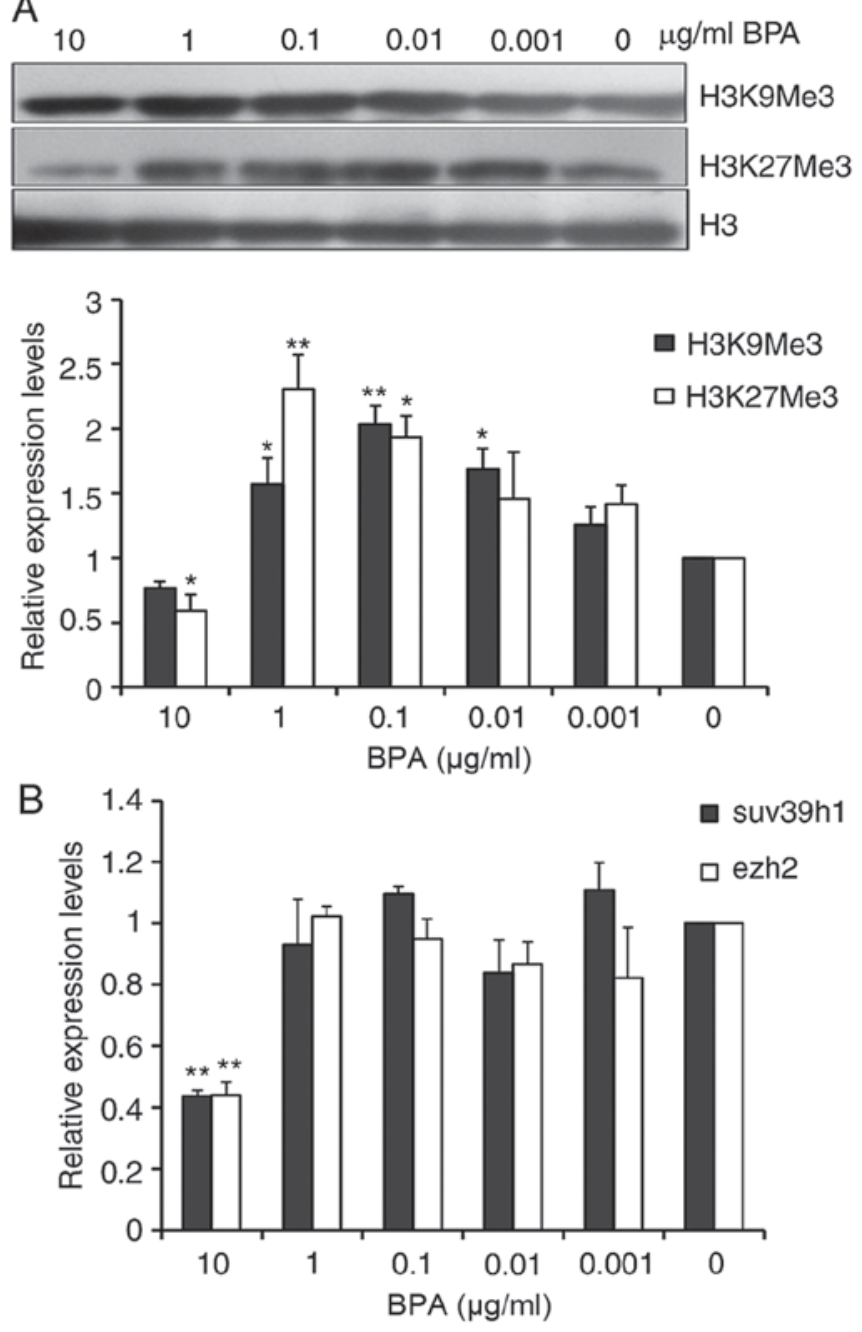

Figure 4. BPA effects on the histone H3 methylation in GC-1 cells. (A) Representative western blots demonstrated alterations in histone methylation levels of $\mathrm{H} 3 \mathrm{~K} 9 \mathrm{Me} 3$ and $\mathrm{H} 3 \mathrm{~K} 27 \mathrm{Me} 3$ in $\mathrm{GC}-1$ cells treated with different concentrations of BPA $(0.001$ to $10 \mu \mathrm{g} / \mathrm{ml})$. The total $\mathrm{H} 3$ was used as a loading control. Histogram represented relative histone methylation levels estimated according to densitometric analysis of bands. Data was normalized to total $\mathrm{H} 3$ and compared to negative control. (B) Reverse transcription-quantitative polymerase chain reaction analysis of mRNA expression of Suv39h1 and Ezh2 in GC-1 cells treated with BPA. Data was normalized to $\beta$-actin and compared with negative control. Error bars represent the standard error of three technical replicates. ${ }^{*} \mathrm{P}<0.05,{ }^{* *} \mathrm{P}<0.01$ vs. control. BPA, bisphenol A; Suv39h1, Suppressor of Variegation 3-9 Homolog 1; Ezh2, Enhancer of Zeste Homolog 2.

statistical significance in the study, due to variance between tests. These contrasting data sets may result from different exposure patterns and duration. These data suggested the underlying mechanisms may be different between high doses and low doses of BPA exposure.

MAPK pathways are important in regulating germ cell cycles and function in spermatogenesis. The present study observed that the significantly increased phosphorylation of p38 was paralleled by a decreased phosphorylation of ERK1/2 at high concentrations of BPA exposure (10 and $1 \mu \mathrm{g} / \mathrm{ml})$. Xia et al (18) reported that p38 MAPK activation and ERK inhibition concurrently are crucial for apoptosis in rat PC-12 pheochromocytoma cells. Therefore, this finding in the study suggested that increased doses of BPA promote apoptosis of GC-1 cells and inhibit cell growth by activating p38 MAPK and suppressing ERK1/2 MAPK. Lower doses of BPA exposure activated p38 and ERK1/2 MAPK. Considering cell proliferation or apoptosis depends on the dynamic balance of the multiple signaling pathways, at present, the specific association between p38, ERK1/2 MAPK alterations and cell growth at low doses of BPA remains to be elucidated.

DNA methylation, an epigenetic modification in which a methyl group is added to the cytosine in a $\mathrm{CpG}$ dinucleotide to produce 5-methylcytosine (5-mC), is important in spermatogenesis, development and germ cell functions. The epigenetic effect of BPA was first demonstrated in the yellow agouti $\left(\mathrm{A}^{\mathrm{vy}}\right)$ mouse model, in which BPA exposure altered the coat color towards yellow by decreasing DNA methylation of $A^{\mathrm{vy}}$ IAP sequence (19). The present study demonstrated that only high doses of BPA exposure (10 and $1 \mu \mathrm{g} / \mathrm{ml}$ of BPA), rather than lower doses of BPA $(0.001$ to $0.1 \mu \mathrm{g} / \mathrm{ml})$, reduced the global DNA methylation levels in spermatogonial cells, using a dot-blot assay. In addition, high doses of BPA induced the reduction of DNMT1 protein and mRNA levels, which resulted in global DNA hypo-methylation and further disrupted the normal development of spermatogonia. A previous study reported that gene expression of DNMT1 is significantly downregulated at $200 \mu \mathrm{M}$ BPA and not at lower concentrations. Expression of DNMT1 is less susceptible to lower doses of BPA in developing hypothalamic cells (20). These results suggested that global DNA methylation alteration occurs in response to BPA exposure.

Research regarding BPA effects on histone methylation has only recently been introduced. However, H3K9Me3 and $\mathrm{H} 3 \mathrm{~K} 27 \mathrm{Me} 3$ have been demonstrated to exhibit repressive effects on gene transcription. In the present study, the mRNA expression of Suv39h1 and Ezh2, and the global levels of $\mathrm{H} 3 \mathrm{~K} 27 \mathrm{me} 3$ were significantly decreased at the high concentration of $10 \mu \mathrm{g} / \mathrm{ml}$ BPA. Zhao et al (21) reported gene silencing of Suv39h1 induces inhibition of cell proliferation via downregulation of histone methylation of H3K9.

Levels of $\mathrm{H} 3 \mathrm{~K} 9 \mathrm{me} 3$ and $\mathrm{H} 3 \mathrm{~K} 27 \mathrm{Me} 3$ were upregulated with exposure to lower concentrations of BPA $(0.01$ to $1 \mu \mathrm{g} / \mathrm{ml})$; however, there were no significant alterations in histone methyltransferase Suv39h1 and Ezh2 mRNA expression. However, it remains unknown whether protein levels or enzyme activities of Suv39h1 and Ezh2 alter. The authors previously demonstrated that $\mathrm{H} 3 \mathrm{~K} 9 \mathrm{me} 3$ levels of zebrafish mature sperm are significantly increased with exposure to $1.5 \mathrm{mg} / 1 \mathrm{BPA}$ in the present laboratory (data not published). Doherty et al (22) reported that the level of $\mathrm{H} 3 \mathrm{~K} 27 \mathrm{Me} 3$ increases in breast cancer MCF-7 cells exposed to BPA at $2.5 \times 10^{-6} \mathrm{M}$, equivalent to $1 \mu \mathrm{g} / \mathrm{ml}$ of BPA in the present study, however the $\mathrm{H} 3 \mathrm{~K} 27 \mathrm{Me} 3$ level and Ezh2 expression at increased doses $(10 \mu \mathrm{g} / \mathrm{ml})$ of BPA were not analyzed.

Epigenetic modifications, including DNA methylation, histone post-translational modifications and ERK1/2 MAPK typically have intimate interactions. DNA methylation promotes histone methylation. Ezh2 has been reported to directly control DNA methylation, thus linking histone methylation and DNA methylation (23). It has previously been demonstrated that DNMTs influence histone 
methylation (24). ERK signaling also has an important role in activity-dependent modifications of histone proteins (25). However, it is not currently clear how this cross talk occurs to precisely regulate the activities in response to diverse circumstances.

The present study demonstrated that inhibition of spermatogonia cell growth occurred at the high doses of BPA exposure $(10 \mu \mathrm{g} / \mathrm{ml})$. It was hypothesized that $\mathrm{p} 38$ MAPK activation is triggered and concurrently inhibits the activity of ERK1/2 to induce cell apoptosis, and also induce global DNA hypomethylation and histone hypomethylation of $\mathrm{H} 3 \mathrm{~K} 27 \mathrm{Me} 3$, which may result in genome instability and finally, inhibition of cell proliferation. Alteration in genomic and epigenetic responses at high and low doses of BPA were observed, however there did not appear to be an association with cell proliferation at the low doses of BPA. Epigenetic alterations resulting from BPA may affect spermatogonia development and complex activities associated with cell proliferation. Therefore, BPA is associated with altered DNA methylation, however the biological effects are still unclear.

In conclusion, the findings using the GC-1 spermatogonia cell model suggested that high and low doses of BPA exposure demonstrated differential effects on cell growth, global DNA methylation and histone H3K9Me3 and H3K27Me3 levels, in addition to MAPK signaling pathways. The varied effects of BPA depending on high or low doses in spermatogonia, implied that complicated underlying mechanisms are involved and remain to be investigated in future studies.

\section{Acknowledgements}

Not applicable.

\section{Funding}

The present study was supported by grants from the National Natural Science Foundation of China (grant nos. 81270760 and 81571495), the National Basic Research Program of China (grant no. 2014CB943104) and Shanghai Municipal Committee of Science and Technology (grant nos. 10ZR1425500 and 15431902800).

\section{Availability of data and materials}

The analyzed data sets generated during the study are available from the corresponding author on reasonable request.

\section{Authors' contributions}

YHL performed western blotting, statistical analysis and drafted the manuscript. FD performed the cell culture and cell proliferation assay, XYZ performed the RT-qPCR assay, HJP performed the dot-blot assay, RSL obtained the funding and designed the study. All authors read and approved the final manuscript.

\section{Ethics approval and consent to participate}

Not applicable.

\section{Consent for publication}

Not applicable.

\section{Competing interests}

The authors declare that they have no competing interests.

\section{References}

1. Chapin RE, Adams J, Boekelheide K, Gray LE Jr Hayward SW, Lees PS, McIntyre BS, Portier KM, Schnorr TM, Selevan SG, et al: NTP-CERHR expert panel report on the reproductive and developmental toxicity of bisphenol A. Birth Defects Res B Dev Reprod Toxicol 83: 157-395, 2008.

2. Geens T, Apelbaum TZ, Goeyens L, Neels H and Covaci A: Intake of bisphenol A from canned beverages and foods on the Belgian market. Food Addit Contam Part A Chem Anal Control Expo Risk Assess 27: 1627-1637, 2010.

3. Lakind JS, Levesque J, Dumas P, Bryan S, Clarke J and Naiman DQ: Comparing United States and Canadian population exposures from National Biomonitoring Surveys: Bisphenol A intake as a case study. J Expo Sci Environ Epidemiol 22: 219-226, 2012.

4. Takeuchi T and Tsutsumi O: Serum bisphenol a concentrations showed gender differences, possibly linked to androgen levels. Biochem Biophys Res Commun 291: 76-78, 2002.

5. Wilson NK, Chuang JC, Morgan MK, Lordo RA and Sheldon LS: An observational study of the potential exposures of preschool children to pentachlorophenol, bisphenol-A, and nonylphenol at home and daycare. Environ Res 103: 9-20, 2007.

6. Susiarjo M, Hassold TJ, Freeman E and Hunt PA: Bisphenol A exposure in utero disrupts early oogenesis in the mouse. PLoS Genet 3: e5, 2007.

7. Batista TM, Alonso-Magdalena P, Vieira E, Amaral ME, Cederroth CR, Nef S, Quesada I, Carneiro EM and Nadal A: Short-term treatment with bisphenol-A leads to metabolic abnormalities in adult male mice. PLoS One 7: e33814, 2012.

8. Jenkins S, Wang J, Eltoum I, Desmond R and Lamartiniere CA: Chronic oral exposure to bisphenol A results in a nonmonotonic dose response in mammary carcinogenesis and metastasis in MMTV-erbB2 mice. Environ Health Perspect 119: 1604-1609, 2011.

9. Motoharu S, Seiichiroh O, Ryuta I, Shuichi K, Masamichi K, Yoshihiro H, Yasunobu A, Junzo Y and Chiharu T: Bisphenol-A affects spermatogenesis in the adult rat even at a low dose. J Occup Health 43: 185-190, 2001.

10. Nagao T, Saito Y, Usumi K, Yoshimura S and Ono H: Low-dose bisphenol A does not affect reproductive organs in estrogen-sensitive $\mathrm{C} 57 \mathrm{BL} / 6 \mathrm{~N}$ mice exposed at the sexually mature, juvenile, or embryonic stage. Reprod Toxicol 16: $123-130,2002$

11. Hofmann MC, Narisawa S, Hess RA and Millán JL: Immortalization of germ cells and somatic testicular cells using the SV40 large T antigen. Exp Cell Res 201: 417-435, 1992.

12. Livak KJ and Schmittgen TD: Analysis of relative gene expression data using real-time quantitative PCR and the 2(-Delta Delta C(T)) method. Methods 25: 402-408, 2001.

13. Ito S, D'Alessio AC, Taranova OV, Hong K, Sowers LC and Zhang Y: Role of Tet proteins in $5 \mathrm{mC}$ to $5 \mathrm{hmC}$ conversion, ES-cell self-renewal and inner cell mass specification. Nature 466: 1129-1133, 2010.

14. Kim EK and Choi EJ: Pathological roles of MAPK signaling pathways in human diseases. Biochim Biophys Acta 1802: 396-405, 2010

15. Li DK, Zhou Z, Miao M, He Y, Wang J, Ferber J, Herrinton LJ, Gao E and Yuan W: Urine bisphenol-A (BPA) level in relation to semen quality. Fertil Steril 95: 625-630.e1-e4, 2011.

16. Bouskine A, Nebout M, Brücker-Davis F, Benahmed M and Fenichel P: Low doses of bisphenol A promote human seminoma cell proliferation by activating PKA and $\mathrm{PKG}$ via a membrane G-protein-coupled estrogen receptor. Environ Health Perspect 117: 1053-1058, 2009.

17. Sheng ZG and Zhu BZ: Low concentrations of bisphenol A induce mouse spermatogonial cell proliferation by $G$ protein-coupled receptor 30 and estrogen receptor- $\alpha$. Environ Health Perspect 119: 1775-1780, 2011. 
18. Xia Z, Dickens M, Raingeaud J, Davis RJ and Greenberg ME: Opposing effects of ERK and JNK-p38 MAP kinases on apoptosis. Science 270: 1326-1331, 1995.

19. Dolinoy DC, Huang D and Jirtle RL: Maternal nutrient supplementation counteracts bisphenol A-induced DNA hypomethylation in early development. Proc Natl Acad Sci USA 104: 13056-13061, 2007.

20. Warita K, Mitsuhashi T, Ohta K, Suzuki S, Hoshi N, Miki T and Takeuchi Y: Gene expression of epigenetic regulatory factors related to primary silencing mechanism is less susceptible to lower doses of bisphenol A in embryonic hypothalamic cells. J Toxicol Sci 38: 285-289, 2013.

21. Zhao T, Ma XD and Huang YQ: Experimental study of SUV39H1 gene specific siRNA in human leukemia cell line. Zhonghua Xue Ye Xue Za Zhi 34: 49-54, 2013 (In Chinese).
22. Doherty LF, Bromer JG, Zhou Y, Aldad TS and Taylor HS: In utero exposure to diethylstilbestrol (DES) or bisphenol-A (BPA) increases EZH2 expression in the mammary gland: An epigenetic mechanism linking endocrine disruptors to breast cancer. Horm Cancer 1: 146-155, 2010.

23. Viré E, Brenner C, Deplus R, Blanchon L, Fraga M, Didelot C, Morey L, Van Eynde A, Bernard D, Vanderwinden JM, et al: The polycomb group protein EZH2 directly controls DNA methylation. Nature 439: 871-874, 2006.

24. Fuks F, Hurd PJ, Deplus R and Kouzarides T: The DNA methyltransferases associate with HP1 and the SUV39H1 histone methyltransferase. Nucleic Acids Res 31: 2305-2312, 2003.

25. Ciccarelli A and Giustetto M: Role of ERK signaling in activity-dependent modifications of histone proteins. Neuropharmacology 80: 34-44, 2014. 